\title{
ANTIOXIDANT ACTIVITY OF MELATONIN AND GLUTATHIONE INTERACTING WITH HYDROXYL AND SUPEROXIDE ANION RADICALS
}

\author{
T. Y. KUZNETSOVA ${ }^{1}$, N. V. SOLOVYOVA², V. V. SOLOVYOV ${ }^{1}$, V. O. KOSTENKO \\ ${ }^{1}$ Yu.Kondratyuk Poltava National Technical University, Ukraine; \\ ${ }^{2}$ Ukrainian Medical Stomatological Academy, Poltava; \\ e-mail:kzt7@ukr.net
}

Based on the analysis of the results obtained by quantum chemical modeling of interaction between reduced glutathione (GSH) and melatonin (MLT) molecules with oxygen radicals $\left(\cdot \mathrm{OH}\right.$ and $\left.\bullet \mathrm{OO}^{-}\right)$it was found that this interaction occured following the acid-base mechanism, where MLT and GSH acted as a base in respect of $\bullet \mathrm{OH}$, and as acid in respect of $\bullet \mathrm{OO}^{-}$. We have carried out the correlation of the results of quantum chemical calculations (density redistribution, energetic characteristics) under the interaction of MLT and GSH molecules with $\bullet \mathrm{OH}$ and $\cdot \mathrm{OO}^{-}$in changing macroscopic properties of the process of electroreduction of free oxygen radicals in the presence of antioxidants (potential and maximal current wave reduction waves). This was a direct experimental macroscale evidence of the results of theoretical modeling at the nanoscale level that pointed to a marked antioxidant activity of glutathione compared with melatonin.

Key word s: antioxidants, melatonin, hydroxyl radical, superoxide anion radical, glutathione.

$\mathrm{T}$ he environment contains the great number of free radicals (FR) which, when found in a human organism, bring to the lesion of proteins, nucleic acids and lipids of biological membranes. Depending on the situation, FR have a mutagenic, cancerogenic or cytostatic effect on the human organism that results in the development of various pathologic states (cancerogenesis, atherosclerosis, chronic inflammations, nervous degenerative diseases, etc.) $[1,2]$. Antioxidants ( $\beta$-carotene, vitamins $\mathrm{C}$ and $\mathrm{E}$, selenium, etc.) are widely used in practical medicine to neutralize the negative effect of FR on human organism [3-5].

Epiphysial hormone - melatonin (MLT) - Nacetyl-5-methoxytryptamine $\left(\mathrm{C}_{13} \mathrm{H}_{16} \mathrm{~N}_{2} \mathrm{O}_{2}\right)$ holds a special position in a series of antioxidants. In the authors' opinion [6-8], it is a more efficient antioxidant in contrast to beta-carotene, vitamins $\mathrm{C}$ and $\mathrm{E}$, selenium and others. Positive results of this hormone application under the treatment of oncologic and other diseases, which were obtained as based on the analysis of medical clinical data only, do not allow understanding the nature of biochemical processes bringing to such a result, and are of purely phenomenological character. One should note a broad discussion concerning antioxidant properties of MLT [9-11], which activity is compared with that of tripeptide glutathione (GSH), and that is not in favor of the latter [10]. Such a conclusion is insufficiently correct since the publications do not include the data of comparative investigations of antioxidant activity of these compounds under the same conditions and at a molecular level. The authors have already established a possibility of such modeling from the results of quantum chemical and electrochemical modeling $[12,13]$. The obtained results bring researchers to a more profound understanding of the mechanism of processes proceeding in vivo with the participation of GSH i MLT, but do not give a direct answer as to their antioxidant activity.

The absence of systematic investigations, especially at a molecular level, of antiradical activity of various antioxidants under their interaction with free radicals in biological systems not only determines the availability of contradictory estimates in interpretation of the results of experimental regulari-

(C) 2017 Kuznetsova T. Y. et al. This is an open-access article distributed under the terms of the Creative Commons Attribution License, which permits unrestricted use, distribution, and reproduction in any medium, provided the original author and source are credited. 
ties [14-17], but also creates difficulties in development of general notions in respect of the mechanism of antioxidants' interaction with free radicals and purposeful approach to governing these processes, practically used in medicine, for example $[11,18]$. So, it seems timely to study the efficiency of the effect of endogenic antioxidants by modeling the mechanism of their interaction with free radicals by the methods of quantum chemistry combined with experimental methods, electrochemical ones in particular.

The work was aimed at studying the reactions of catalytic oxidation of melatonin and glutathione with superoxide anion radical $\left(\cdot \mathrm{OO}^{-}\right)$and hydroxylradical $(\cdot \mathrm{OH})$ under equal conditions on the basis of the results of electrochemical investigations and their comparative analysis with characteristics of quantum-chemical calculations.

\section{Materials and Methods}

Theoretical study of the mechanism of MLT and GSH interaction with $\cdot \mathrm{OO}^{-}$and $\bullet \mathrm{OH}$ was performed with the help of the program module GAMESS-US [19] and the program module Firefly 8 by the non-empirical quantum chemical method in the basis $6-31 G^{* *}$ [20]. The dissolvent effect on the properties of the systems under study was calculated using the polarized continuum models (PCM).

Electrochemical investigations of modeling of GSH interaction with free oxygen radicals using differential impulse voltammetry were carried out jointly with researchers of the Institute of Bioorganic Chemistry and Petrochemistry of NAS of Ukraine. L-glutathione of SERVA company and melatonin of Merck company were applied to prepare the solution. The compounds were used without additional purification.

\section{Results and Discussion}

To analyze the antioxidant activity of MLT and GSH molecules it is principally important to establish the most active centers of these molecules interaction with free oxygen radicals. To search for the "attack directions" of melatonin and glutathione molecules by free oxygen radicals the authors have made the calculations of distribution of molecular electrostatic potential (MESP) in $\cdot \mathrm{OH}$ and $\cdot \mathrm{OO}^{-}$ radicals and MLT and GSH molecules. It was established in accordance with calculations that for -OH there is a minimum of MESP localized near oxygen atom, and for $\cdot \mathrm{OO}^{-}$, on the contrary, its iso- tropic distribution is observed. The obtained difference of such distribution of MESP should be necessarily one of determining factors in establishing the mechanism of MLT and GSH interaction with radicals, since they, having one nonpaired electron, will "attack" MLT and GSH molecules in directions with positive MESP values.

To search for minima of full energy, corresponding to maxima of $\cdot \mathrm{OH}$ and $\cdot \mathrm{OO}^{-}$interaction with MLT i GSH molecules, a detailed scanning of the surface of full interaction energy has been performed in the vicinity of "attack places" of MLT and GSH molecules by calculation of the transition state of interaction reaction. When determining the activation energy, for each of the "attack directions", when an angle changes between the corresponding interatomic bonds of antioxidant molecules and radicals and of corresponding distances between the atoms of reagents, it was established that GSH molecule has 17, while MLT molecule has 16 minimums of full energy, including the global one (Fig. 1).

When GSH molecule interacted with one $\cdot \mathrm{OO}^{-}$ in the point of global minimum of full interaction energy, the redistribution of a charge of $0.702 \mathrm{e}$ from $\cdot \mathrm{OO}^{-}$to glutathione molecule through the atom of hydrogen $\mathrm{H}(23)$ occurred. This suggests a possibility of efficient interaction of $\cdot \mathrm{OO}^{-}$and GSH with a probable formation of stable complexes (Fig. 2, A). This process occurred similarly under $\cdot \mathrm{OO}^{-}$interaction with melatonin molecule (transfer of a $0.664 \mathrm{e}$ charge from superoxide anion radical oxygen atoms to MLT molecule) that resulted in the change of the bond length both in the free radical from 0.136 to $0.143 \mathrm{~nm}$ and in melatonin molecule $\mathrm{N}(8)-\mathrm{H}(14)$ from 0.0999 to $0.142 \mathrm{~nm}$ (Fig. 2, B).

And on the contrary, the electron density increased on the hydroxyl-radical oxygen atom by $0.208 \mathrm{e}$ under interaction with one $\cdot \mathbf{O H}$; as a result the bond length $\mathrm{S}(22)-\mathrm{H}(23)$ increased in glutathione molecule from 0.132 to $0.317 \mathrm{~nm}$, that indicated a possibility of detachment of this hydrogen atom from GSH molecule and addition to $\cdot \mathrm{OH}$ with formation of water molecule (Fig. 3, A).

The increase of electron density for "isolated" hydroxyl-radical under interaction with hydrogen atom $\mathrm{H}(14)$ (in global minimum of full energy) of MLT molecule was about $0.229 \mathrm{e}$; as a result the bond length between nitrogen and hydrogen atoms $\mathrm{N}(8)-\mathrm{H}(14)$ increased in melatonin molecule from 0.0999 to $0.311 \mathrm{~nm}$ (Fig. 3, B), thus suggesting a probability of this hydrogen atom detachment from 
A $\quad \mathrm{E} \cdot 10^{-5}, \mathrm{~kJ} / \mathrm{mol}$

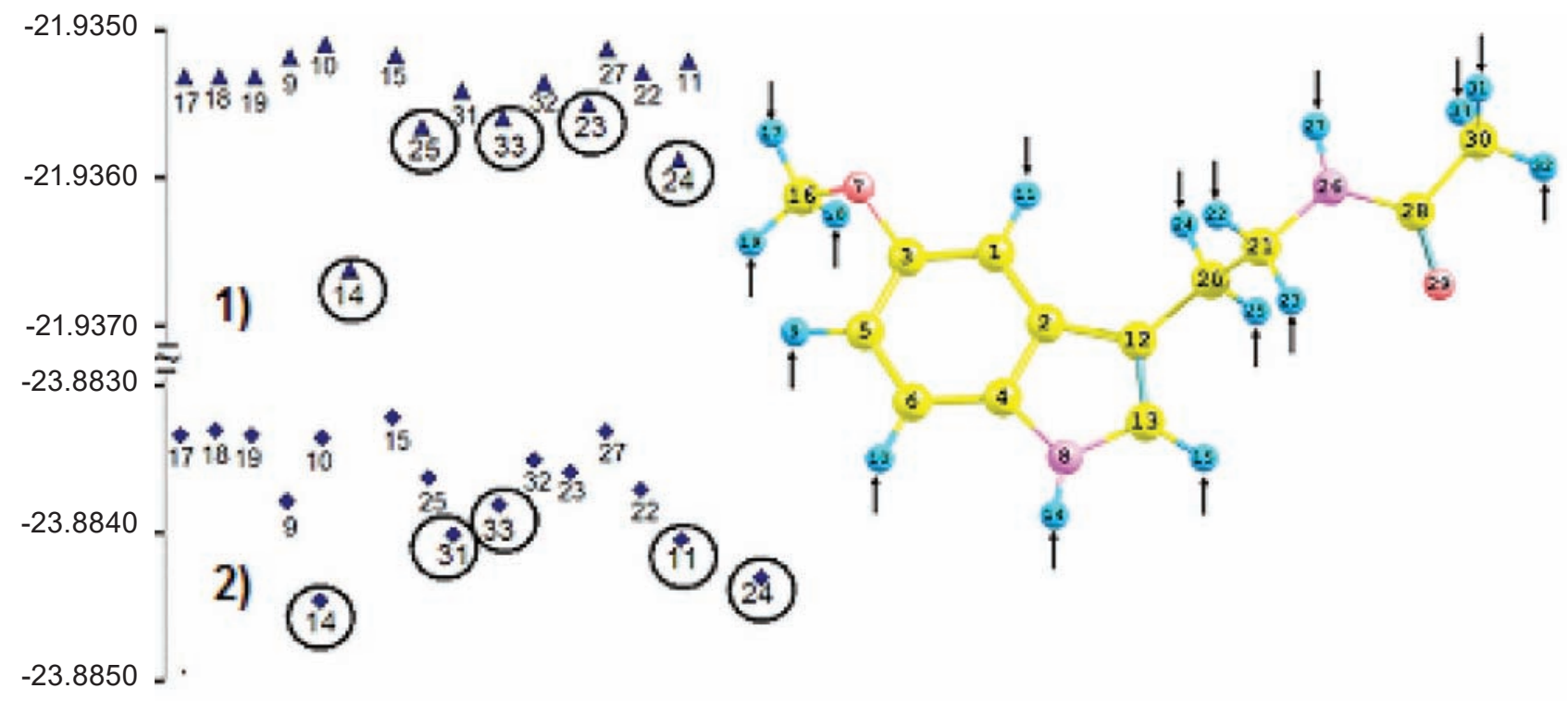

B $\quad \mathrm{E} \cdot 10^{-5}, \mathrm{~kJ} / \mathrm{mol}$

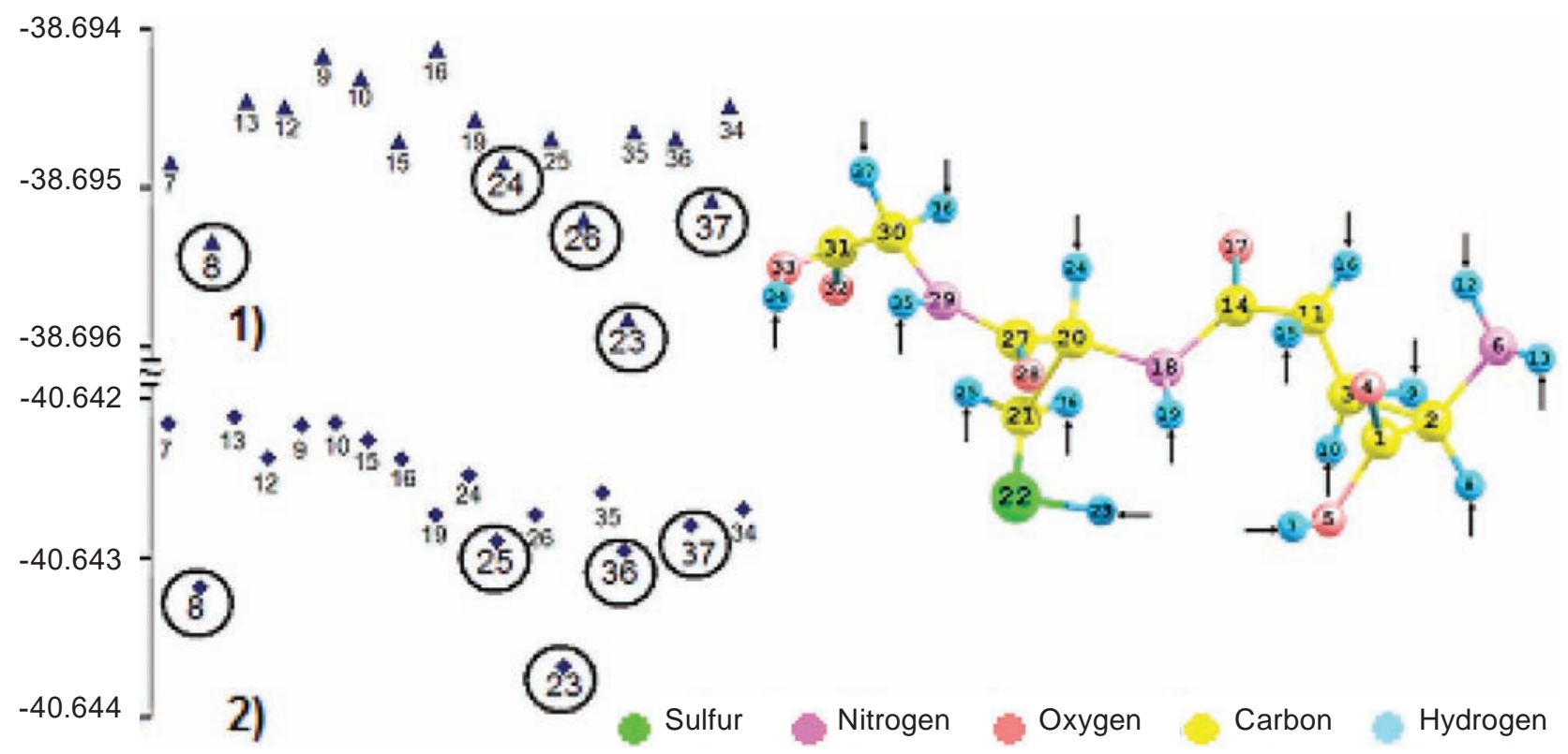

Fig. 1. Minimums of full interaction energy (E) in complexes: $\left.\boldsymbol{A}-\mathrm{MLT} \cdots \cdot \mathrm{OH}\left[\bullet \mathrm{OO}^{-}\right] ; \mathbf{B}-\mathrm{GSH} \cdots \bullet \mathrm{OH}^{-} \cdot \mathrm{OO}^{-}\right]$ under the "attack" of various centers of antioxidant molecules by free radicals: $\mathbf{1}-\bullet \mathrm{OH} ; \mathbf{2}-\bullet \mathrm{OO}^{-}(5$ the deepest minimums - $\mathrm{O}$ are distinguished)

MLT molecule and its addition to $\cdot \mathrm{OH}$ with formation of water molecule.

Modeling of radical $\left(\cdot \mathrm{OO}^{-}\right.$and $\left.\bullet \mathrm{OH}\right)$ concentration change relative to antioxidant molecules has shown, that simultaneous interaction of five radicals in both cases with MLT and GSH molecules does not change as a whole the character of redistribution of electron density for interaction with one radical, but makes it a "softer" one.
Thus the interaction of a molecule of the studied antioxidant with free oxygen radicals initiates heterodirected redistribution of electron density in molecules antioxidants (Fig. 4).

The effect of water medium on the mechanism of antioxidant molecules interaction with free oxygen radicals has been modeled within the program Firefly 8 to bring the results of quantum chemical modeling closer to real conditions of the interaction 

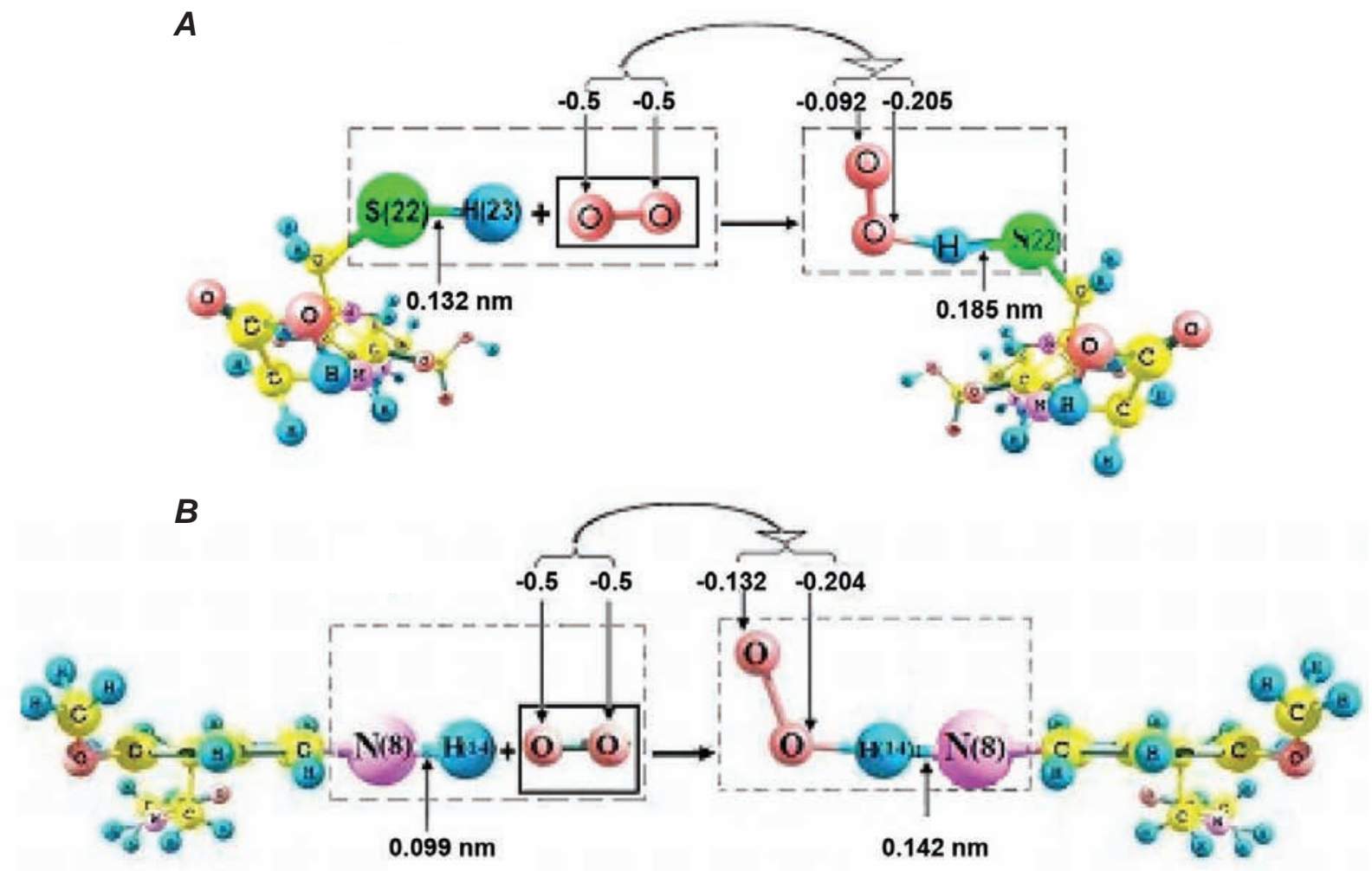

Fig. 2. Scheme of molecules interaction: $\mathbf{A}-G S H ; \boldsymbol{B}-M L T$ with $\bullet O O^{-}$(arrows show charges on atoms by Lyovdin)

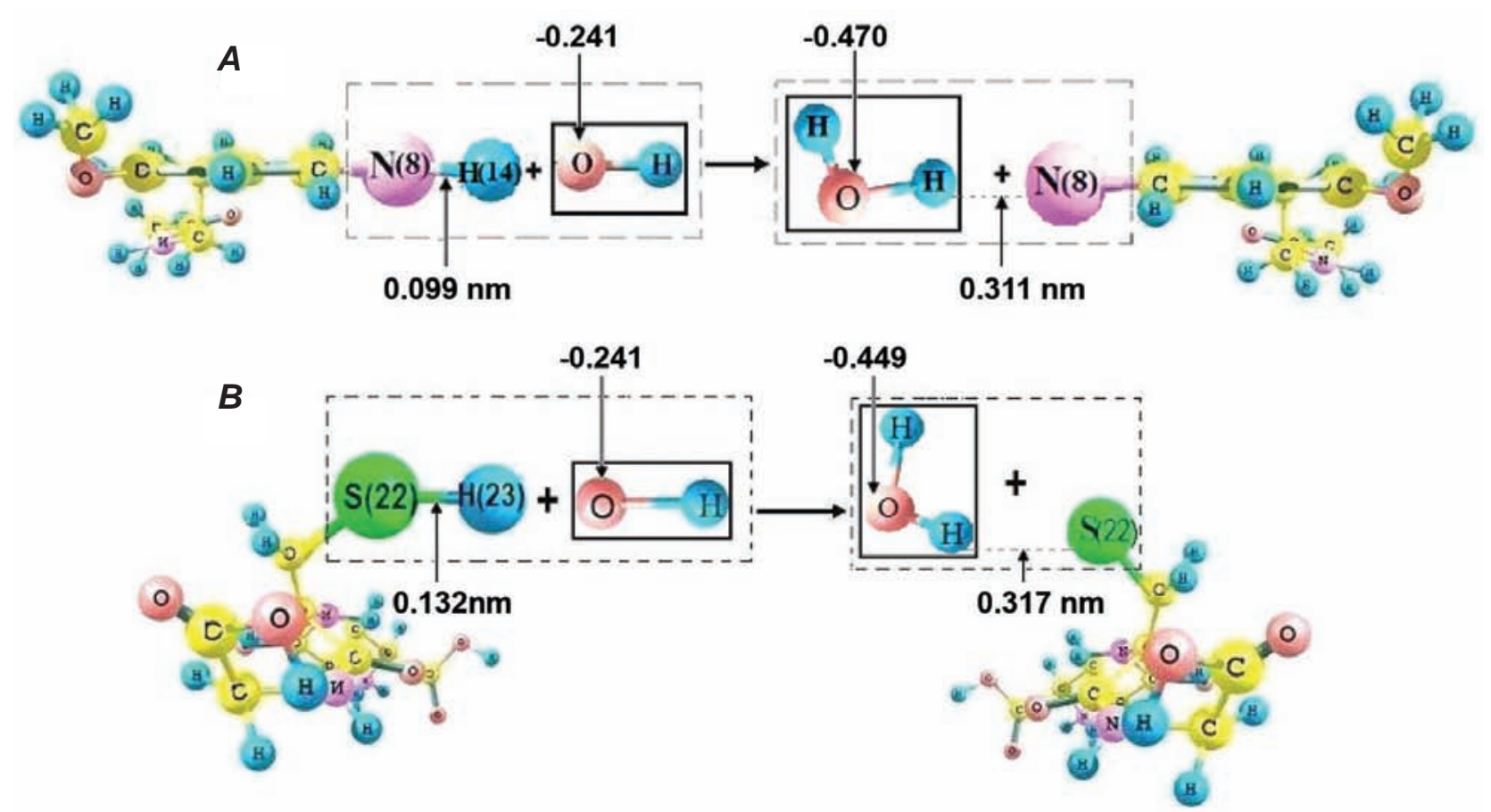

Fig. 3. Scheme of molecules interaction: $\boldsymbol{A}-G S H ; \boldsymbol{B}-M L T$ with $\bullet O H$ (arrows show charges on atom by Lyovdin) 


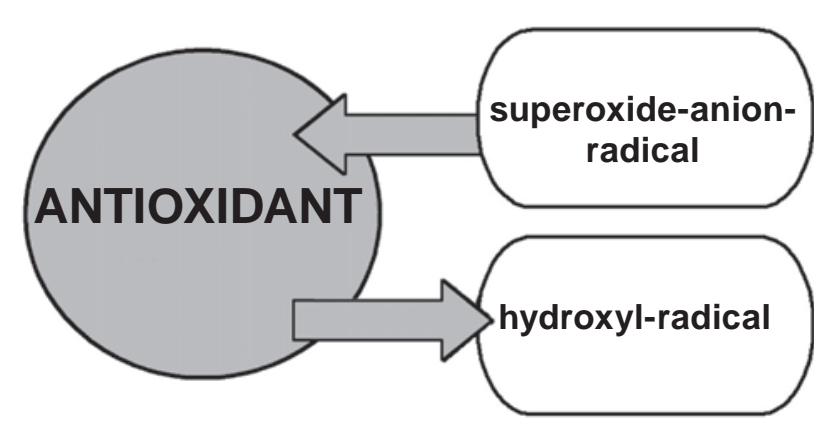

Fig. 4. Scheme of redistribution of electron density under interaction of MLT $i$ GSH molecules with $\bullet \mathrm{OH}$ and $\cdot \mathrm{OO}^{-}$

of MLT and GSH molecules with $\bullet \mathrm{OH}$ and $\cdot \mathrm{OO}^{-}$in the human organism. The analysis of the obtained results has shown that the mechanism of redistribution of electron density, allowing for the effect of water medium with dielectric constant $\varepsilon=78.355$ at $\mathrm{T}=298 \mathrm{~K}$ within the continual model of the solvent PCM (polarized continuum model) for these interactions, remains almost unchanged that is confirmed by the comparison of charges distribution according to Lyovdin, corresponding distances in MLT, GSH, $\cdot \mathrm{OH}$ and $\cdot \mathrm{OO}^{-}$, as well as the values of activation energies for the reactions of antioxidant molecule interactions with $\bullet \mathrm{OH}$ and $\cdot \mathrm{OO}^{-}$(Table 1,2$)$.

Thus, quantum chemical modeling of interaction of MLT and GSH molecules with $\bullet \mathrm{OH}$ and $\cdot \mathrm{OO}^{-}$ has shown that the change in radicals concentration in respect of antioxidant and allowance for the effect of water medium do not radically affect the redistribution of electron density of antioxidants' molecules and permits concluding that the studied reactions occur following the acid-base mechanism; under these conditions the antioxidant molecule act as a base in respect of $\bullet \mathrm{OH}$ and as an acid in respect of $\bullet \mathrm{OO}^{-}$in agreement with the established scheme (Fig. 4).

To confirm the conclusions obtained from the results of quantum chemical modeling, the electrochemical studies of MLT and GSH interaction with free oxygen radicals have been conducted in water physiologic solution using the method proposed at the Institute of Bioorganic Chemistry and Petrochemistry of NAS of Ukraine [21].

Differential voltammetric curves of reduction of free oxygen radicals, which characterize reactions (1-3) analogous to those proceeding in biosystems in the process of respiration, metabolism, oxygen stress:

Ta b le 1. Comparative distribution of charges $q$ by Lyovdin and activation energy Ea under interaction of MLT and GSH molecules with free oxygen radicals in the global minimum point

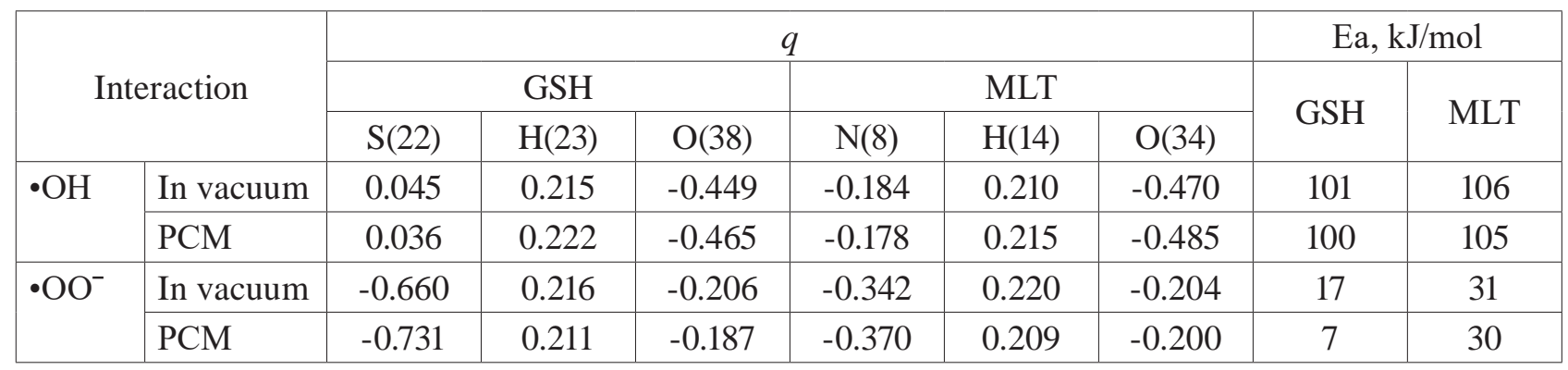

Ta ble 2. Comparative distribution of the bonding orders Bij and distances $R$ under MLT $i$ GSH molecules interaction with free oxygen radicals in the point of global minimum

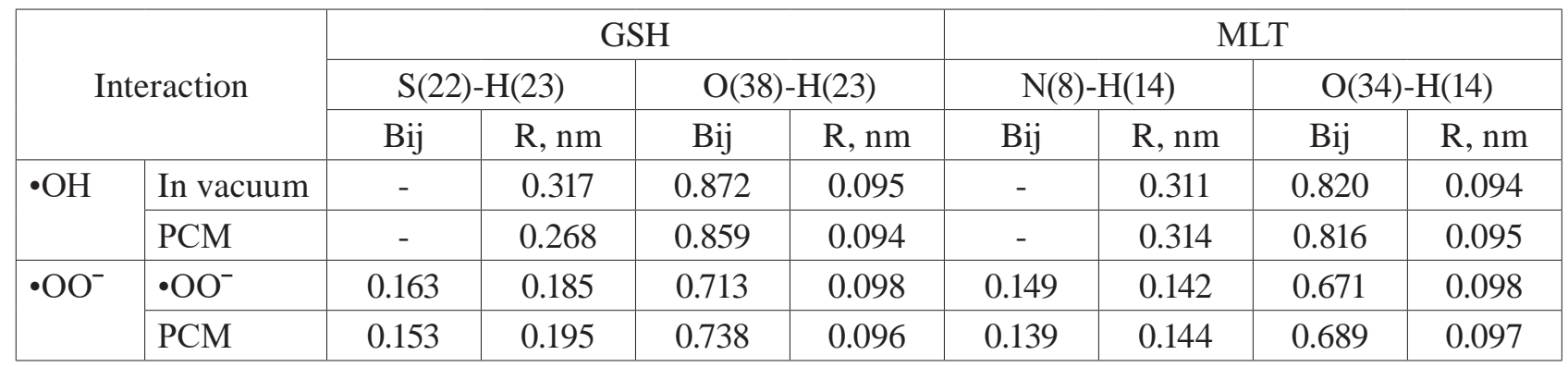


wave I $(\mathrm{E}=-0.2 \mathrm{~B})$

$\cdot \mathrm{OH}+\mathrm{e}^{-} \rightarrow \mathrm{OH}^{-}$,

wave II $(\mathrm{E}=-0.7 \mathrm{~B})$

$\mathrm{O}_{2}+1 \mathrm{e}^{-} \rightarrow \cdot \mathrm{OO}^{-}$,

$\cdot \mathrm{OO}-+1 \mathrm{e}^{-}+2 \mathrm{H}+\rightarrow \mathrm{H}_{2} \mathrm{O}_{2}$,

wave III $(\mathrm{E}=-1,1 \mathrm{~B})$

$\mathrm{H}_{2} \mathrm{O}_{2}+\mathrm{e}^{-} \rightarrow{ }^{-} \mathrm{OH}+\cdot \cdot \mathrm{OH}$,

were plotted on the background of $0.1 \mathrm{M}$ solution of $\mathrm{NaCl}$ in water (physiological solution) with further titration of background electrolyte by additions of MLT and GSH of different concentration (Fig. 5).

MLT and GSH additions of different concentration being introduced into the background solution, the appearance of three waves was observed. Therewith the reduction potential $(\varphi)$ of the first wave did not change that indicates the reduction of electrochemically activated particles (EAP) which are the same in type and form. The increase of concentrations of MLT and GSH additions led to the essential decrease of limit current of the first waves on voltammogram at the expense of purely chemical inhibition reaction in the volume phase of the solution according to the scheme (4):

$$
\begin{aligned}
& \mathrm{C}_{13} \mathrm{H}_{16} \mathrm{~N}_{2} \mathrm{O}_{2}\left[\mathrm{C}_{10} \mathrm{H}_{17} \mathrm{~N}_{3} \mathrm{O}_{6} \mathrm{~S}\right]+\cdot \mathrm{OH} \rightarrow \\
& \rightarrow \cdot \mathrm{C}_{13} \mathrm{H}_{15} \mathrm{~N}_{2} \mathrm{O}_{2}\left[\cdot \mathrm{C}_{10} \mathrm{H}_{16} \mathrm{~N}_{3} \mathrm{O}_{6} \mathrm{~S}\right]+\mathrm{H}_{2} \mathrm{O},
\end{aligned}
$$

That points to the decrease of EAP quantity of $\cdot$ OH type.

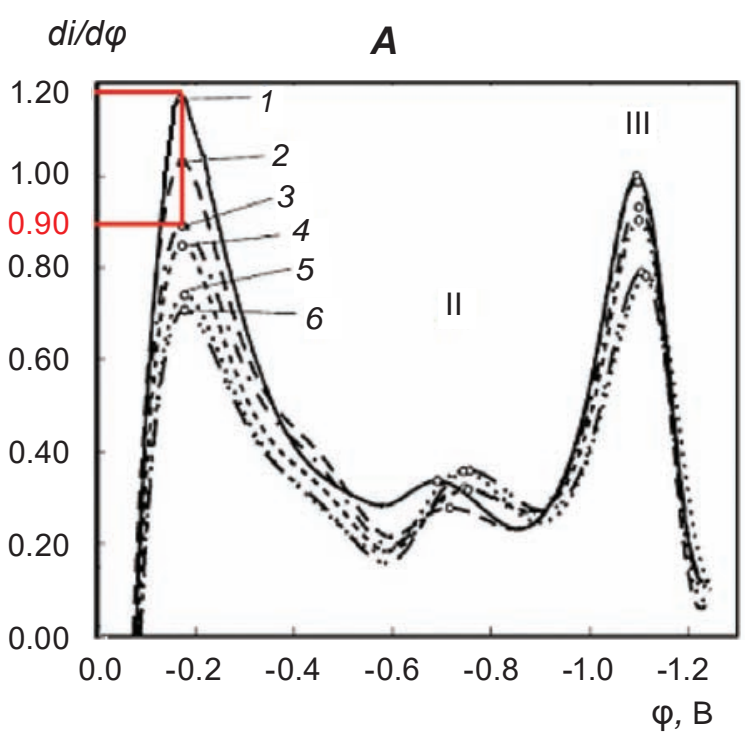

Further reduction of $\bullet \mathrm{OH}$, which concentration decreases as a result of reaction (4) when introducing MLT[GSH] additions, will be observed under the unchanged potential $(0.2 \mathrm{~V})$ on the electrode by the following reaction:

$$
\cdot \mathrm{OH}^{-}+1 \overline{\mathrm{e}} \rightarrow \mathrm{OH}^{-} \text {. }
$$

It should be noted (Fig. 1) that in the presence of MLT and GSH additions with the same concentration $0.74 \cdot 10^{-3} \mathrm{M} / \mathrm{dm}^{3}$, one could observe a considerable decrease of limit current of first waves of reduction compared with the background (relative value of the current peak is 1.7 times higher in the presence of GSH, and approximately 1.2 times higher for MLT) indicating more expressed antiradical properties of GSH compared to MLT.

In contrast to the first wave, the cathode shift of the second wave of renewal potential was observed under introduction of MLT and GSH additions. The results of quantum chemical investigations of $\cdot \mathrm{OO}^{-}$ interaction with antioxidants did not point to the breaking of hydrogen bonds in MLT and GSH molecules. Complexation probability and experimentally found cathode shift of the potential of 2 reduction waves for both cases pointed uniquely to the process of reduction of electroactive complexes, which type, form and quantity will be determined by MLT and $\mathrm{GSH}$ concentration in respect to $\cdot \mathrm{OO}^{-}$.

$\mathrm{The} \cdot \mathrm{OO}^{-}$reduction wave in the presence of GSH shifted towards a decrease of reduction po-

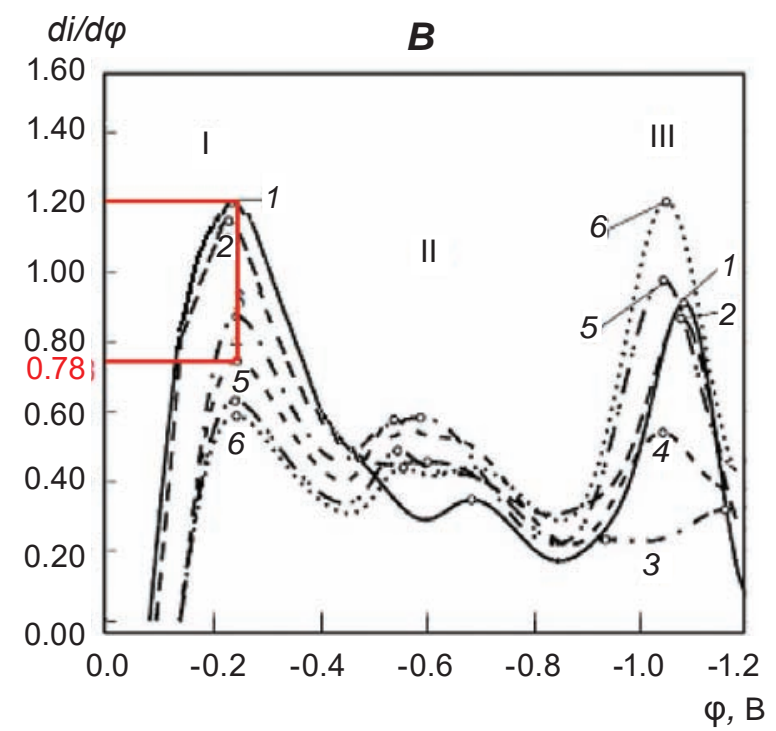

Fig. 5. Differential voltamperograms of FR reduction on a copper cathode on the background of $0.1 \mathrm{M} \mathrm{NaCl}$ in water (1) in the presence of various concentrations of antioxidants: MLT (A): $2-0.39 ; 3-0.74 ; 4-1.07$;

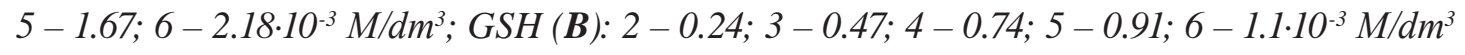


tential value, and in the presence of MLT - towards an increase that also confirms more expressed antiradical properties of GSH compared to MLT in respect of $\bullet \mathrm{OO}^{-}$. Such a substantiation of the shift of the second wave in the process of a single-electron reduction of EAP correlates with results of quantum chemical estimation of activation energy values under single-electron charge transfer (Fig. 6), which are different for the "isolated" $\cdot \mathrm{OO}^{-}$molecule and for complexes $\left\{\mathrm{MLT} \cdot \mathrm{OO}^{-}\right\}$and $\left\{\mathrm{GSH} \cdot \mathrm{OO}^{-}\right\}$. The reduction potential invariability and a decrease of the limit current (wave 1) and cathode shift of the potential (wave 2) with the increase of concentration of antioxidants in interaction with free radicals for both cases is a direct corroboration at the level of results of quantum chemical calculations at the nanolevel.

So, the obtained experimental results have confirmed at a macrolevel the results of quantum chemical investigations and have shown that MLT and GSH display antiradical activity, and under these conditions, more expressed antiradical properties of glutathione compared with melatonin were corroborated [10]. It should be noted that the result obtained (reaction 4) coincides qualitatively with the results of medical research by S. O. Bachurin [11], presented in a form of phenomenological scheme of MLT interaction with free oxygen radicals in the human organism.

Thus, the analysis of results of quantum chemical modeling served as a basis for establishing the most probable centers of the interaction of MLT and GSH molecules with free oxygen radicals, which correspond to the deepest minima of full energy of their interaction. The authors have studied the mechanism of interaction of MLT and GSH molecules with $\cdot \mathrm{OH} \mathrm{i} \cdot \mathrm{OO}^{-}$, which has shown that the reaction between antioxidants and radicals follows the acid-base mechanism, and in so doing antioxidants act as a base in respect of $\bullet \mathrm{OH}$ and as an acid in respect of $\bullet \mathrm{OO}^{-}$. The conducted electrochemical investigations have confirmed antioxidant properties of MLT and GSH, and thus research have confirmed on the macroscopic level the cardinal difference of the mechanisms of inhibition of hydroxyl radicals and superoxide anion radicals by molecules of antioxidants on the background of prevailing antiradical activity of GSH compared to MLT.

The correlation of change of macroscopic parameters in the process of electroreduction of active oxygen forms in the presence of MLT and GSH (the potential and limit current of the reduction waves)

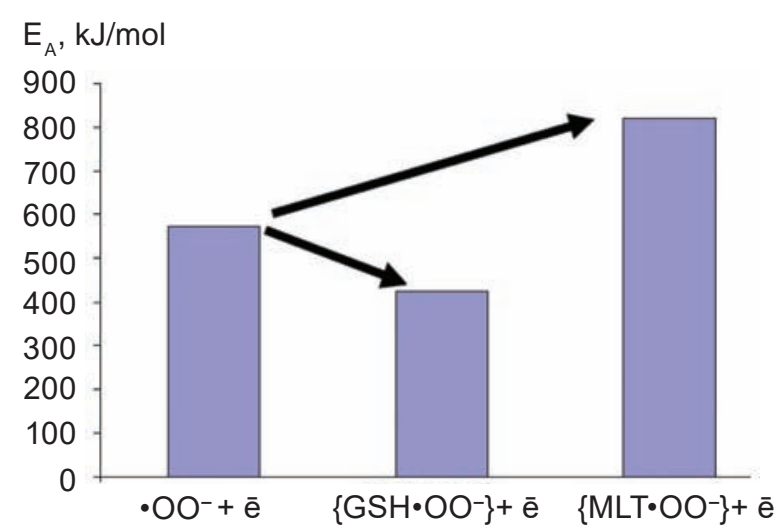

Fig. 6. Diagram of changing the values of activation barriers for $\cdot \mathrm{OO}^{-}$and its complexes and a singleelectron renewal

has been established as well as the results of quantum chemical research obtained on the nanolevel (redistribution of electron density, the orders of bonds between atoms, energetic characteristics) under the interaction of antioxidant molecules with free oxygen radicals.

A perspective of using the results of quantum chemical calculations combined with electrochemical research for substantiating and establishing peculiarities and differences of antioxidant activity of melatonin, glutathione under the interaction with superoxide anion radical and hydroxyl radical with the aim to predict the ways of creating new medical drugs was established.

\section{АНТИОКСИДАНТНА АКТИВНІСТЬ МЕЛАТОНІНУ І ГЛУТАТІОНУ ЗА ВЗАСМОДІї 3 ГІДРОКСИЛ- І СУПЕРОКСИД АНІОН- РАДИКАЛАМИ}

\section{Т. Ю. Кузнечова ${ }^{1}$, Н. В. Соловйова ${ }^{2}$, В. В. Соловйов ${ }^{1}$, В. О. Костенко}

\author{
${ }^{1}$ Полтавський національний технічний \\ університет ім. Ю. Кондратюка, Україна; \\ ${ }^{2}$ Українська медична стоматологічна \\ академія, Полтава; \\ e-mail: kzt7@ukr.net
}

На основі аналізу результатів квантовохімічного моделювання взаємодії молекул мелатоніну (MLT) і глутатіону (GSH) iз радикалами кисню $\left(\cdot \mathrm{OH}\right.$ i $\left.\cdot \mathrm{OO}^{-}\right)$встановлено, що вона відбувається за кислотно-основним механізмом, причому MLT i GSH по 
відношенню до •ОН виступають як основа, а до $\cdot \mathrm{OO}^{-}-$як кислота. Проведено кореляцію квантовохімічних розрахунків (перерозподіл електронної густини, енергетичні характеристики) за взаємодії молекул MLT i GSH iз $\bullet \mathrm{OH} \mathrm{i} \bullet \mathrm{OO}^{-}$ зі зміною макроскопічних параметрів процесу електровідновлення вільних радикалів кисню в присутності антиоксидантів (потенціал та граничний струм хвиль відновлення), що є прямим підтвердженням на макрорівні результатів проведеного на нанорівні теоретичного моделювання та вказує на більш виражену антиоксидантну активність GSH у порівнянні із MLT.

К л юч о в і с ло в а: антиоксидант, гідроксил-радикал, супероксид аніон-радикал, глутатіон, мелатонін.

\section{АНТИОКСИДАНТНАЯ АКТИВНОСТЬ МЕЛАТОНИНА И ГЛУТАТИОНА ПРИ ВЗАИМОДЕЙСТВИИ С ГИДРОКСИЛ- И СУПЕРОКСИД АНИОН-РАДИКАЛАМИ}

\section{Т. Ю. Кузнеиова ${ }^{1}$, Н. В. Соловьева ${ }^{2}$, В. В. Соловьев ${ }^{1}$, В. А. Костенко}

\footnotetext{
${ }^{1}$ Полтавский национальный технический университет им. Ю. Кондратюка, Украина; ${ }^{2}$ Украинская медицинская стоматологическая академия, Полтава; e-mail: kzt7@ukr.net
}

На основе анализа результатов квантовохимического моделирования взаимодействия молекул мелатонина (MLT) и глутатиона (GSH) с радикалами кислорода $\left(\cdot \mathrm{OH}\right.$ и $\left.\cdot \mathrm{OO}^{-}\right)$установлено, что оно происходит по кислотно-основному механизму, причем MLT и GSH по отношению к -ОН выступают как основание, а по отношению к $\cdot \mathrm{OO}^{-}$- как кислота. Проведена корреляция квантовохимических расчетов (перераспределение электронной плотности, энергетические характеристики) при взаимодействии молекул MLT и GSH c $\cdot O H$ и $\cdot \mathrm{OO}^{-}$с изменением макроскопических параметров процесса электровосстановления свободных радикалов кислорода в присутствии антиоксидантов (потенциал и предельный ток волн восстановления), что является прямым экспериментальным подтверждением на макроуровне результатов проведенного на наноуровне теоретического моделирования и ука- зывает на более выраженную антиоксидантную активность GSH по сравнению с MLT.

К л ючевы е с лов а: антиоксидант, гидроксил-радикал, супероксид анион-радикал, глутатион, мелатонин.

\section{References}

1. Parasuraman S, Maithili KS. Antioxidant and drug metabolism. Free Rad Antiox. 2014; 4(1): 01-02.

2. What Are Free Radicals? [Electronic resource]. Access mode//https://www. globalhealingcenter. com/natural-health/what-are-free-radicals/.

3. Lobo V, Patil A, Phatak A, Chandra N. Free radicals, antioxidants and functional foods: Impact on human health. Pharmacogn Rev. 2010; 4(8): 118-126.

4. Sparman A, Thompson K. Safety Profile and Effect on Libido of a Combined Bryophyllum pinnatum, Moringa oleifera and Vitamin C Phytotherapeutic Agent. Free Rad Antiox. 2017; 7(2): 156-159.

5. Naidu JN, Swapna GN, Kumar AN, Krishnamma M, Anitha M. Importance of elevated insulin resistance, dyslipidemia and status of antioxidant vitamins in polycystic ovary disease. Free Rad Antiox. 2013; 3(1): 1719.

6. Belenichev IF, Gubsky YuI, Levitsky EL, Kovalenko SI, Marchenko AN. Regulation of antioxidant homeostasis and system detoxication of organizm by hormone melatonin. Role of melatonin dependent receptors in realization of this function. Modern Probl Toxicol. 2003; (2): 2-16. (In Russian).

7. Malinovskaya NK. The role of melatonin in the human body. Klin Med. 1998; (10): 15-22. (In Russian).

8. Dawson D, van den Heuvel CJ. Integrating the actions of melatonin on human physiology. Ann Med. 1998; 30(1): 95-102.

9. Kvetnaya TV, Knyazkin IV. Melatonin: role and importance in age-related pathology. St. Petersburg, 2003. 93 p. (In Russian)

10. Reiter RJ. Melatonin: Lowering the High Price of Free Radicals. News Physiol Sci. 2000; 15: 246-250.

11. Bachurin SO. Medicinal and chemical approaches to focused search of agents for treatment and therapy of Alzheimer disease. Vopr Med Khim. 2001; 47(2): 155-197. (In Russian). 
12. Kuznetsova TY, Solovyova NV. Simulation of antioxidant properties of melatonin and glutathione in contact with hydroxyl radicals. Actual Probl Mod Med. News Ukr Med Stomat Acad. 2012; 12(1-2): 189-193. (In Russian).

13. Solovyova NV, Kuznetsova TY. Quantum chemical modeling of antioxidant activity of glutathione interacting with hydroxyl- and superoxide anion radicals. Ukr Biochem J. 2015; 87(2): 156-162.

14. Magin DV, Izmaylov DIu, Popov IN, Levin G, Vladimirov IuA. Photochemiluminescent study of the antioxidant activity in biological systems. Mathematical modeling. Vopr Med Khim. 2000; 46(4): 419-425. (In Russia).

15. Ehlenfeldt MK, Prior RL. Oxygen radical absorbance capac ity (ORAC) and phenolic and anthocyanin concentrations in fruit and leaf tissues of highbush blueberry. J Agricult Food Chem. 2001; 49(5): 2222-2227.

16. Korotkova EI, Karbainov YA, Shevchuk AV. Study of antioxidant properties by voltammetry. J Electroanal Chem. 2002; 518(1): 56-60.
17. Korotkova EI, Karbainov YA, Avramchik OA. Investigation of antioxidant and catalytic properties of some biologically active substances by voltammetry. Anal Bioanal Chem. 2003; 375(3): 465-468.

18. Prütz WA, Butler J, Land EJ. The glutathione free radical equilibrium, mediating electron transfer to FE(III) -cytochrome c. Biophys Chem. 1994; 49(2): 101-111.

19. General Atomic and Molecular Electronic Structure System. [Electronic resource]. Access mode //http://www.msg.ameslab.gov/ gamess/.

20. Alex A. Granovsky. Firefly and PC GAMESS /Firefly version 8.0.1. [Electronic resource]. Access mode //http://classic.chem.msu.su/gran/ gamess/index.html.

21. Shapoval GS, Kruglyak OS, Kuznetsova TYu, Soloviev VV, Nestyuk NV. Electrocatalytic oxidation of natural endogenous antioxidants. Catal Petrochem. 2009; (17): 31-38. (In Russian).

Received 04.10.2017 